\title{
$\underline{\mathbf{P}-125}$
}

\section{Antibacterial and Antifungal Potential of Local Lawsonia Inermis}

\author{
Zainab Razali* and Hasnun Nita Ismail
}

Faculty ofApplied Science, Universiti Teknologi MARA (Perlis), 02600 Arau, Perlis, Malaysia 02600 Arau, Perlis, Malaysia; E-mail: zainab215@perlis.uitm.edu.my

\begin{abstract}
Antimicrobial and antifungal are the most significant weapons in fighting infections and have greatly benefited the healthrelated quality of human life. In this study, antimicrobial and antifungal effects of Local Lawsonia inermis against bacteria isolated from human mouth and scalp fungus isolated from human head (dandruff) were investigated by using the disc diffusion method. Extraction technique of L. inermis using four types of solvents: methanol, ethanol, acetone and hexane. At different concentration, extractions are injected onto Muller-Hilton and Potato Dextrose Agar, respectively. The potential of L.inermis extract as an antibacterial and antifungal are determined by the formation of inhibition zone around the well. From the result, all L.inermis crude extracts using solvent ethanol showed fascinating antibacterial activity against both bacteria and scalp fungus. The $400 \mathrm{mg} / \mathrm{ml}$ of extract was most effective against bacteria isolated from human mouth (16mm) whereas scalp fungus was found to be the most inhibited at $500 \mathrm{mg} / \mathrm{mL}(20 \mathrm{~mm})$ compared to other treatments. This study shows the potential of our local L.inermis for replacement of synthetic antibacterial and antifungal agent by the use of natural extracts.
\end{abstract}

Keywords: Antimicrobial, Antifungal, Local Lawsonia inermis, Synthetic. 